\begin{tabular}{|ll|}
\hline & $\begin{array}{l}\text { International Journal of Advanced Engineering, Management } \\
\text { and Science (IJAEMS) } \\
\text { INF( GAIN }\end{array}$ \\
Peer-Reviewed Journal \\
ISSN: 2454-1311 / Vol-7, Issue-12; Dec, 2021 \\
Journal Home Page: https://ijaems.com/ \\
Article DOI: https://dx.doi.org/10.22161/ijaems.712.2
\end{tabular}

\title{
Customer Shift to Online Transactions: Benefits to Local Small Food Business
}

\author{
Maria Anastacia B. Alquiroz ${ }^{1}$, Mary Joy S. Fernando ${ }^{2}$, Ariane May L. Gonzales ${ }^{3}$, Jervie \\ P. Hipolito ${ }^{4}$, Niña May C. Iquio ${ }^{5}$, Arjhel V. Domingo ${ }^{6}, \mathrm{PhD}$
}

\author{
${ }^{1}$ MBA Student, Nueva Ecija University of Science \& Technology, Philippines \\ ${ }^{2}$ Philippine Carabao Center, Philippines \\ ${ }^{3}$ Waltermart Shopping Center Management, Inc., Philippines \\ ${ }^{4}$ Philend Lending Investors, Inc., Philippines \\ ${ }^{5}$ Concentrix, Philippines \\ ${ }^{6}$ Faculty, NEUST Graduate School, , Philippines
}

Received: 21 Oct 2021; Received in revised form: 28 Nov 2021; Accepted: 10 Dec 2021; Available online: 16 Dec 2021

\begin{abstract}
The emergence of E-commerce and the change in customers' behavior to online shopping, especially in this pandemic, has led the local small enterprises to shift to online transactions. This study aimed to determine the benefits to local small enterprises of the food industry when operators and customers have shifted to online transactions and its effects on their sales, marketing cost, administrative costs and employment. The food operators were respondents in this study. Findings revealed that sales were not affected despite the shift to online transaction. In fact, this is the best platform to advertise and market the product. Marketing costs, on the other hand, were reduced if not maintained, because of less physical movement and the requirement of paraphernalia. Administrative costs that consist of wages and status of employment were at status quo. No retrenchment was made, however, modifications in job assignments and description were made. Since online transaction is never infallible, fraud is rampant. Spoilages and food degradation are of utmost concern in the food sector industry.
\end{abstract}

Keywords-Administrative cost-wages and employment, food industry, marketing cost reduction, small enterprises, sales.

\section{INTRODUCTION}

Micro, small, and medium enterprises (MSMEs) play a critical role in developing the Philippine economy since they alleviate poverty by providing jobs to millions of Filipinos around the country (The MSME Sector at a Glance, 2012). Before the pandemic, the Philippine economy was expanding in urban and rural areas, and businesses engaged in wholesaling and retailing were making substantial profits using traditional sales methods. With the onset of COVID 19, everything changed for MSMEs, including the development and growth of online shopping sites. Local businesses can use digital technology to help them keep up with their sales. Consumers are looking for stores where they may pay with their credit and debit cards conveniently; yet, they cannot find this in local
MSMEs, prompting them to turn to online transactions. Another reason why customers are shifting to online commerce is that online store prices are typically lower than retail prices in malls, providing benefit and convenience in buying. Business owners that stay up with the new trend of online shopping have joined those huge websites to stream their items and sell online, giving them access to thousands of potential customers from throughout the country and increasing their sales. However, not all business owners have the correct perspective to adapt online business, particularly in rural regions. Some businesses do not want to leave their comfort zone, which is their old business model, and they do not want to learn the new business trend. To persuade 
them, you may need to show them the advantages of ecommerce in sales and profitability.

According to Pillemer (2020), one benefit of ecommerce for businesses is lower costs. Doing online business can reduce fixed costs because of the absence of a physical store. No more construction for shops, lower utility expenses, lower salaries because of the fewer staff and lower advertising expenses because of social media for marketing that can cause lower prices for the products that lead to an increase in sales. It needs more storage space which is less costly than physical store space, and accurate inventory that serves as a detector for purchasing new merchandise. This study aims to determine the benefits to local micro and small enterprises when customers shifted to online transactions in sales, marketing cost, administrative cost, and employment (Ivanov, 2012). Furthermore, the study also aims to propose an action plan that can help enhance the operation of Small Enterprises in San Jose City, Nueva Ecija.

\section{METHODOLOGY}

The descriptive research method was used in this study. It is a quantitative research design that explores and evaluates the characteristics and trends of the situation (Mc Combes, 2019). The researchers gathered data thru researchers-made questionnaire with various survey questions on sales, marketing cost, and administrative costs and employment to the respondents. There were 50 respondents given personally to the business establishments. Only 32 were answered. Data collected were consolidated and measured using weighted mean.

\begin{tabular}{|c|c|c|}
\hline Weight & Mean Range & Interpretation \\
\hline 4 & $3.51-4.50$ & Always \\
\hline 3 & $2.51-3.50$ & Often \\
\hline 2 & $1.51-2.50$ & Sometimes \\
\hline 1 & $1.00-1.50$ & Never \\
\hline
\end{tabular}

\section{RESULTS AND DISCUSSION}

\section{Sales}

Table 1.1 SALES

\begin{tabular}{|c|c|c|}
\hline ITEM STATEMENT & $\begin{array}{l}\text { Weighted } \\
\text { Mean }\end{array}$ & $\begin{array}{c}\text { Verbal } \\
\text { Interpretation }\end{array}$ \\
\hline 1. The adoption of online transactions increase my daily sales. & 3.24 & Often \\
\hline $\begin{array}{l}\text { 2. I agree that online transaction has its advantages in terms of sales } \\
\text { as compared to the traditional method. }\end{array}$ & 3.30 & Always \\
\hline 3. The adoption of online transactions increase product exposure. & 3.52 & Always \\
\hline 4. My business offers a promo or sale through online transactions. & 2.94 & Often \\
\hline $\begin{array}{l}\text { 5. My everyday business sales quota was achieved after adopting the } \\
\text { online transaction. }\end{array}$ & 2.85 & Often \\
\hline $\begin{array}{l}\text { 6. When doing business online, I worked closely with my marketing } \\
\text { team to promote my product and goods online. }\end{array}$ & 3.12 & Often \\
\hline $\begin{array}{l}\text { 7. When it comes to driving sales, my representative focus on top } \\
\text { buyers like those who buy in greater amount and those who are in a } \\
\text { repeated basis to prioritize and keep them. }\end{array}$ & 2.82 & Often \\
\hline 8. I consistently post/update my products/goods online. & 3.06 & Often \\
\hline $\begin{array}{l}\text { 9. Posting photos and other related descriptions of my product help me } \\
\text { to attract more customers online. }\end{array}$ & 3.52 & Always \\
\hline Average Weighted Mean & 3.15 & Often \\
\hline
\end{tabular}

Table 1.1 shows the responses about the sales of the business owners. The average weighted mean of 3.15 interpreted as Often only signifies that using online selling and transactions have not affected the respondents' sales since the food sector has always been a prime commodity. This article can be downloaded from here: $w w w . i j a e m s . c o m$
More so, the customers find this online setup more convenient and less time consuming to transact. Promoting products and services through social media and other online platforms will enable you to get more exposure for your brand and business, eventually 
delivering profitable results (Boost Your Social Media Exposure with These 6 Innovative Strategies, 2021). Business owners opted to focus on social media marketing today because it's the most effective to target customers and to drive sales into the business rather than focusing only on limited top buyers. Shifting to an online transaction is a way for small businesses to help them recover during the pandemic wherein most businesses had been temporarily closed and out of business. There is a strong possibility in regaining sales on the side of the business owners and help to mitigate the economic downturn since customers also shift to online shopping (How Covid-19 Triggered the Digital and E-commerce Turning Point, 2021).

\section{Marketing Cost}

Table 1.2 Marketing Cost

\begin{tabular}{|c|c|c|}
\hline ITEM STATEMENT & Weighted Mean & $\begin{array}{l}\text { Verbal } \\
\text { Interpretation }\end{array}$ \\
\hline $\begin{array}{l}\text { 1. The cost for advertisement increased when I shifted to online } \\
\text { transactions. }\end{array}$ & 2.27 & Seldom \\
\hline $\begin{array}{l}\text { 2. The cost for marketing my product increased when I shifted to } \\
\text { online transactions. }\end{array}$ & 2.45 & Seldom \\
\hline $\begin{array}{l}\text { 3. I joined groups on social media platforms to promote the } \\
\text { business via networking my products. }\end{array}$ & 3.24 & Often \\
\hline $\begin{array}{l}\text { 4. I created community-building groups for my target audience or } \\
\text { customers online. }\end{array}$ & 2.42 & Seldom \\
\hline 5. I did employee retrenchment during the pandemic. & 2.00 & Seldom \\
\hline 6.I saw the business progressed when I shifted online. & 3.21 & Often \\
\hline $\begin{array}{l}\text { 7. My employees become more efficient when the business shifted } \\
\text { to online transactions. }\end{array}$ & 2.85 & Often \\
\hline $\begin{array}{l}\text { 8. I have made my marketing and advertising activities more } \\
\text { efficient. }\end{array}$ & 3.30 & Always \\
\hline $\begin{array}{l}\text { 9. I was able to give incentives to my employees because of the } \\
\text { reduced cost in marketing. }\end{array}$ & 3.06 & Often \\
\hline Average Weighted Mean & 2.76 & Often \\
\hline
\end{tabular}

Table 1.2 shows the responses about the marketing cost of the respondents in the use of online selling and transactions. Reduction in the marketing cost was more evident shifting to online as platform to promote and sell the product. In shifting to online transactions, there is a possible acceleration of sales because of the new normal trend. Hence additional workforce has been demanded. Retailers who shifted to online transactions benefited greatly and accelerated their sales growth (Perez,2020). Small business owners who engage in online business rarely retrench employees during the pandemic because their businesses are still doing good, and many of them accelerated their sales and need employees who will continue to work with them.

\section{Administrative Costs: Wages and Employment}

Table 1.3 Administrative Cost: Wages, Employment

\begin{tabular}{lcr}
\hline \multicolumn{1}{c}{ ITEM STATEMENT } & Weighted Mean & $\begin{array}{c}\text { Verbal } \\
\text { Interpretation }\end{array}$ \\
\hline $\begin{array}{l}\text { 1. I retrenched some of my employees when I adopted to online } \\
\text { transactions. }\end{array}$ & 1.85 & Seldom \\
$\begin{array}{l}\text { 2. Shifting to online transactions required more employees than } \\
\text { traditional selling. }\end{array}$ & 2.18 & Seldom \\
3. I imposed incentives on employees when they hit the online sales & 2.52 & Seldom
\end{tabular}

This article can be downloaded from here: $\underline{w w w . i j a e m s . c o m}$ 
quota.

4. My operational cost was reduced when I adopted to online

Seldom transactions aside from traditional selling.

5. My employees shifted to other duties and responsibilities when I

Seldom shift to online transactions.

6. My employees needed the training and skills required for the new set up of online transactions.

7. My employees were required to render overtime and finish all responsibilities when I shifted to online transactions.

8. I reduced the wages expenses and save money from paying my employees' salaries when I shifted to online transactions.

9. My employees' wages were still under minimum wage when I shifted to online transactions.

2.42
Seldom

Never

Never

Seldom
Average Weighted Mean

The average weighted mean of 2.10 or equivalent to Seldom verbal interpretation reveal that administrative costs have not increased despite the pandemic, while shifting to online transaction was found to be equally efficient. This has not also affected the current number of employees these establishments maintained despite the covid-19 pandemic. Many businesses had been affected by the negative impact of a pandemic on their business that caused them to close, and "more than half of the SMEs are facing severe losses in revenue" (Tackling Corona Virus (Covid 19) Contributing to a Global Effort, 2020). For them, this is the recovery period; this is why it is hard to impose incentives when their employees hit the sales quota. Their priority is to recover first to sustain their business and their employees. As soon as the business can restore from loss, it would be easy for them to bring back some benefits for their employees. Even the government focuses on the recovery of the businesses first, helping SMEs to back up from the wave of loss during the pandemic (Government Support has Helped Save Many But Challenges Remain- OECD, 2021). And when recovery already happened, benefits to employees can easily be restored.

\section{CONCLUSION AND RECOMMENDATIONS}

\section{Conclusion}

Sales. Seldom that sales were affected using the online platform in marketing and selling the product. At some point that this adoption of technological advancements has further heightened the respondents' selling activities to discover another way to a more efficient operation.
Marketing Cost. The shift to online has made the product more exposed to consumers, while keeping at bay the respondents' marketing costs. This has led to make the operating costs instead save for employee welfare in the form of incentive.

Administrative costs: wages and employment. Contrary to other beliefs, the use of online has not affected the employment of its workers, however there are some modifications in the duties and responsibilities of employees because of the change in the environment.

\section{RECOMMENDATIONS}

1. Continuous upgrading in the use of websites and gadgets is a must in online transaction.

2. They should be more cautious in using online transaction because of rampant fraud.

3. Control and sanitary practices must be strictly implemented especially those in the food business since spoilages, product degradation is prevalent while those are in transit.

\section{REFERENCES}

[1] Abelardo, L., Lomboy, M., Lopez, C., Balaria, F., \& Subia, G. (2019). Challenges Encountered by the National High School Teachers in Doing Action Research. International Journal of English, Literature and Social Science (IJELS).Vol-4, Issue-4, Jul - Aug 2019 https://dx.doi.org/10.22161/ijels.4418 ISSN:2456-7620.

[2] Boost Your Social Media Exposure with These 6 Innovative Strategies, (2021). Retrieved from https://digitalmarketingphilippines.com

[3] Covid-19 Has Changed Online Shopping Forever, Survey Shows, (2020). Retrieved from http://unctad.org.>news 
[4] E-commerce in the time of COVID-19, (2020). Retrieved from https://www.oecd.org/coronavirus/policy-responses/ecommerce-in- the-time-of-covid-19-3a2b78e8/

[5] E-Commerce Questionnaire. Retrieved from https://www.scribd.com/doc/30690767/E-CommerceQuestionnaire

[6] Government Support Has Helped Saved Money SMEs But Challenges Remain - OECD, (2021). Retrieved from https://www.oecd.org/gfe/smes

[7] How E-commerce Has changed Customer Behavior, (2018). Retrieved from http://www.scalefast.com $>$ blog

[8] How Covid-19 Triggered the Digital and E-commerce Turning Point, (2021). Retrieved from http://unctad.org.>news

[9] Perez, S., (2020). Covid-19 Pandemic Accelerated Shift to Commerce by 5 Years, New Report Says.

[10] Pillemer, N., (2020). 10 Advantages of E-commerce for Consumers \& Businesses. Retrieved from http://www.divaportal.org/smash/get/diva2:538119/FULLTEXT01.pdf

[11] The MSME Sector at A Glance, (2012). Retrieved from http://senate.gov.ph

[12] Small Business Owners' View on Health Coverage and Costs, (2019). Retrieved from https://www.cdc.gov.>community

[13] Tackling Corona Virus (Covid 19) Contributing to a Global Effort, (2020). Retrieved from https://www.oecd.org>coronavirus

[14] Ivanov, Diyan (2012). The Impact of E-Commerce on Small Size Companies in Sweden.

[15] Pandemic has Forever Changed Online Shopping, UNBacked Survey Reveals, (2020). Retrieved from https://news.un.org >story> 2020/10

[16] Mina, J.C., Subia, G.S., Barlis, P.T., Tuliao, R.C. and Pastorfide, P.M. (2020). Inclinations of Engineering and Marketing Management Students to Engage in Online Learning Technology Amidst the COVID-19 Pandemic. Technology Reports of Kansai University, ISSN: 04532198, Volume 62, Issue 09 